\title{
Evidence for vivianite formation and its contribution to long-term phosphorus retention in a recent lake sediment: a novel analytical approach
}

\author{
M. Rothe ${ }^{1,2}$, T. Frederichs ${ }^{3}$, M. Eder ${ }^{4}$, A. Kleeberg ${ }^{1, *}$, and M. Hupfer ${ }^{1}$ \\ ${ }^{1}$ Leibniz-Institute of Freshwater Ecology and Inland Fisheries, Berlin, Germany \\ ${ }^{2}$ Department of Geography, Humboldt University of Berlin, Berlin, Germany \\ ${ }^{3}$ Department of Geosciences, University of Bremen, Bremen, Germany \\ ${ }^{4}$ Department of Biomaterials, Max Planck Institute of Colloids and Interfaces, Potsdam, Germany \\ *now at: State Laboratory Berlin Brandenburg, Kleinmachnow, Germany
}

Correspondence to: M. Rothe (rothe@igb-berlin.de)

Received: 25 April 2014 - Published in Biogeosciences Discuss.: 21 May 2014

Revised: 26 August 2014 - Accepted: 27 August 2014 - Published: 26 September 2014

\begin{abstract}
Vivianite, $\mathrm{Fe}_{3}\left(\mathrm{PO}_{4}\right)_{2} \cdot 8 \mathrm{H}_{2} \mathrm{O}$, is a ferrous iron phosphate mineral which forms in waterlogged soils and sediments. The phosphorus $(\mathrm{P})$ bound in its crystal lattice is considered to be immobilised because vivianite is stable under anoxic, reducing, sedimentary conditions. Thus, vivianite formation can make a major contribution to $\mathrm{P}$ retention during early diagenesis. Much remains unknown about vivianite in sediments, because technical challenges have rendered direct identification and quantification difficult. To identify vivianite and assess its significance for $\mathrm{P}$ burial during early diagenesis we studied the consequences of a 1992/1993 in-lake application of $\mathrm{FeCl}_{3}$ and $\mathrm{Fe}(\mathrm{OH})_{3}$ aimed at restoring Lake Groß-Glienicke (Berlin, Germany). In a novel approach, we firstly applied a heavy-liquid separation to the iron-rich surface sediments which allowed direct identification of vivianite by X-ray diffraction in the high-density $\left(\rho>2.3 \mathrm{~g} \mathrm{~cm}^{-3}\right)$ sediment fraction. Secondly, we assessed the contribution of vivianite to $\mathrm{P}$ retention, combining results from chemical digestion with magnetic susceptibility data derived from magnetic hysteresis measurements. Scanning electron microscopy revealed that the dark blue spherical vivianite nodules were $40-180 \mu \mathrm{m}$ in diameter, and formed of platy- and needle-shaped crystal aggregates. Although equilibrium calculations indicated supersaturation of vivianite throughout the upper $30 \mathrm{~cm}$ of the sediment, the vivianite deposits were homogeneously distributed within, and restricted to, the upper $23 \mathrm{~cm}$ only. Thus, supersaturated pore water alone can-
\end{abstract}

not serve as a reliable predictor for the in situ formation of vivianite. In Lake Groß-Glienicke, vivianite formation continues to be triggered by the artificial iron amendment more than 20 yr ago, significantly contributing to $\mathrm{P}$ retention in surface sediments.

\section{Introduction}

Understanding phosphorus (P) dynamics in aquatic ecosystems has been of particular interest among researchers for almost a century. Since $P$ is an important nutrient limiting primary production, the cycling of $\mathrm{P}$, and the role of the sediments in regulating $\mathrm{P}$ availability in the water column have been studied intensively. Long-term burial of $\mathrm{P}$ in sediments is the only mechanism able to shield $\mathrm{P}$ from continuous (re)-cycling, and therefore represents an output of $\mathrm{P}$ from the internal nutrient cycle (Katsev et al., 2006; Hupfer and Lewandowski, 2008).

The burial of $\mathrm{P}$ depends on several processes (Ruttenberg, 1992; Søndergaard et al., 2001) and fixation is of either organic or inorganic phases. Organic $\mathrm{P}$ originates from settled organic material which is refractory or not yet mineralised by microorganisms. Inorganic phases include $\mathrm{P}$ sorbed onto the surface of iron(oxy)hydroxides, aluminium hydroxides, clays and calcite (Moosmann et al., 2006). P associated with $\mathrm{Fe}(\mathrm{III})$ minerals have been found in anoxic marine 
and estuarine sediments, indicating a resistance towards reductive dissolution of these compounds, at least under nonsulfidic conditions (Hyacinthe and Van Cappellen, 2004; Lehtoranta et al., 2009). Thus, during sediment diagenesis there may be the formation of stable phosphate minerals which bind $\mathrm{P}$ in their crystal lattice and contribute to permanent P burial (see e.g. Jilbert and Slomp, 2013). However, the processes controlling the $\mathrm{P}$ burial under anoxic conditions are still not fully understood (e.g. Stigebrandt et al., 2013).

One specific phosphate mineral which forms during sediment diagenesis is the ferrous phosphate vivianite, $\mathrm{Fe}_{3}\left(\mathrm{PO}_{4}\right)_{2} \cdot 8 \mathrm{H}_{2} \mathrm{O}$. The mineral is a regularly found deposit in sedimentary cores (e.g. Brauer et al., 1999; Fagel et al., 2005; Sapota et al., 2006; Minyuk et al., 2013). Since P is only a minor constituent in sediments, the direct identification of vivianite is difficult. While a large fraction of total $\mathrm{P}$ can be organic or sorbed $\mathrm{P}$, vivianite may comprise only a small part of the inorganic sediment matrix (Lindsay et al., 1989).

In natural systems, vivianite is stable under $\mathrm{pH}$ conditions from 6 to 9 (Nriagu, 1972) and can form in waterlogged soils and sediments (Berner, 1981). The precipitation of vivianite directly from pore water solution is favoured by high concentrations of ferrous iron ( $\mathrm{Fe}(\mathrm{II}))$ and soluble reactive $\mathrm{P}$ (SRP) often found in anoxic non-sulfidic environments (Nriagu, 1972; Nriagu and Dell, 1974; Roden and Edmonds, 1997). By flux calculations Emerson and Widmer (1978) demonstrated that mineral formation is surface- rather than diffusion-controlled, and hence there is no equilibrium control by vivianite with respect to pore water SRP and $\mathrm{Fe}^{2+}$ concentrations (Postma, 1981). Recently, Walpersdorf et al. (2013) confirmed that vivianite does not control phosphate solubility in an anoxic meadow soil.

The literature has reported vivianite crystal aggregates to be needle-shaped or spherical with diameters ranging between a few micrometres to several centimetres. Upon exposure to air, the crystals turn vivid blue due to partial oxidation of $\mathrm{Fe}^{2+}$ (Hush, 1967). As ferric iron (Fe(III))-phases and organic matter serve as source material for $\mathrm{Fe}^{2+}$ and SRP, vivianite often occurs in the vicinity of these phases. Laboratory studies show that vivianite appears as a secondary mineral product following $\mathrm{Fe}(\mathrm{III})$ reduction by dissimilatory iron-reducing bacteria (DIRB) if sufficient $\mathrm{PO}_{4}^{3-}$ is present in the culture medium (e.g. Borch and Fendorf, 2007; O'Loughlin et al., 2013).

All these findings indicate that the interplay between the availability of source materials (Fe(III)-phases, organic matter), the activity of DIRB and their cell-mediated microenvironments, as well as the pore structure of the sediment matrix, are important in vivianite formation. However, direct evidence of vivianite in recent sediments (e.g. Nembrini et al., 1983; Hearn et al., 1983; Manning et al., 1991; Taylor et al., 2008; Nanzyo et al., 2013) appears to be scarce. Often the claim of vivianite findings is solely based upon indirect measures, such as equilibrium calculations, sequential $\mathrm{P}$ extrac- tions, or electron microprobe analysis lacking direct identification. The difficulty in identifying vivianite in a sediment matrix might be a reason why there is limited knowledge about the quantitative importance of vivianite formation in $\mathrm{P}$ burial during early diagenesis.

To address this need, the aims of our present study were to: (1) identify vivianite crystal aggregates from recent lake sediment showing favourable formation conditions in the pore water, (2) determine the significance of vivianite formation for $\mathrm{P}$ burial during early diagenesis, and (3) assess the impact of artificial addition of Fe during lake restoration as a trigger for vivianite formation. For these purposes we developed and applied a novel analytical approach, combining heavy-liquid separation of surface sediments followed by mineral identification by X-ray diffraction, elemental analyses and magnetic hysteresis measurements.

\section{Material and methods}

\subsection{Study site}

Lake Groß-Glienicke is a dimictic lake located southwest of Berlin, Germany $\left(52^{\circ} 27^{\prime} 57^{\prime \prime} \mathrm{N}, 13^{\circ} 06^{\prime} 39^{\prime \prime} \mathrm{E}\right)$, with a mean depth of $6.8 \mathrm{~m}$, a maximum depth of $11 \mathrm{~m}$, and a surface area of $0.67 \mathrm{~km}^{2}$. Until 1992 the lake was highly eutrophic, and had on average total P (TP) and chlorophyll $a(\mathrm{Chl} a$ ) concentrations of $485 \mu \mathrm{g} \mathrm{L}^{-1}$ and $41 \mu \mathrm{g} \mathrm{L}^{-1}$ (1989-1992) (Kleeberg et al., 2013). To reduce the $\mathrm{P}$ concentration in the water column, the lake was treated with solid ferric hydroxide $\left(\mathrm{Fe}(\mathrm{OH})_{3}\right)$ and dissolved ferric chloride $\left(\mathrm{FeCl}_{3}\right)$ between December 1992 and February 1993 (Wolter, 2010). Due to decreased external $\mathrm{P}$ inputs and the in-lake $\mathrm{P}$ precipitation, TP and Chl $a$ decreased reaching today's mesotrophic levels of TP $20 \mu \mathrm{g} \mathrm{L}^{-1}$ and Chl $a 7 \mu \mathrm{g} \mathrm{L}-1$. Sediment stratigraphy shows a distinct increase in $\mathrm{Fe}$ and $\mathrm{P}$ content corresponding to the time of the in-lake treatment. Today, this shift is evident at a sediment depth of $23 \mathrm{~cm}$. Both Fe and TP contents in the sediment almost doubled after the treatment, reaching $33 \mathrm{mg} \mathrm{g}^{-1}$ dry weight and $2.6 \mathrm{mg} \mathrm{g}^{-1}$ dry weight (Kleeberg et al., 2012). Due to the iron's redox sensitivity iron and TP contents are higher throughout the newly formed sediment which has accumulated since the in-lake treatment in 1992/93.

\subsection{Sample collection and preparation}

\subsubsection{Porewater}

To document the geochemical conditions within the upper $30 \mathrm{~cm}$ of the sediment, we used two in situ dialysis samplers (Hesslein, 1976) each with 14 chambers and a vertical resolution of $4 \mathrm{~cm}$. The samplers were filled with deionised water and covered by a $0.2 \mu \mathrm{m}$ membrane filter $\left(\right.$ Gelman ${ }^{\circledR}$ HT 200 Tuffryn). To remove oxygen from the chamber water the samplers were degassed with nitrogen for $24 \mathrm{~h}$ and 
subsequently deployed at the deepest site in the lake for $20 \mathrm{~d}$ in September 2013 during thermal stratification.

\subsubsection{Sediment}

Sediment cores $35-40 \mathrm{~cm}$ long and $60 \mathrm{~mm}$ in diameter were taken in September 2012 and May 2013 by a gravity corer (UWITEC) at the deepest site in the lake. Two hours after sampling the cores were extruded, immediately sectioned into $20 \mathrm{~mm}$ slices, frozen, and freeze-dried for at least $72 \mathrm{~h}$. The freeze-dried sediment served as raw material for further analysis and is in the following text referred to as "bulk" sediment.

Subsamples of freeze-dried sediment (about $1 \mathrm{~g}$ dry weight) were homogenised by gentle pestling in an agate mortar, and subsequently sieved through $80 \mu \mathrm{m}$ and $63 \mu \mathrm{m}$ stainless steel meshes. Only the largest size fraction $(\geq 80 \mu \mathrm{m})$ was used and thereafter separated by density using two different concentrations of a sodium polytungstate solution $\left(3 \mathrm{Na}_{2} \mathrm{WO}_{4} \cdot 9 \mathrm{WO}_{3} \cdot \mathrm{H}_{2} \mathrm{O}, \mathrm{ABCR}\right)$. In step I, a sediment sample of approximately $0.3 \mathrm{~g}$ was mixed in a centrifuge tube with $10 \mathrm{~mL}$ of sodium polytungstate solution (density $\rho=1.9 \mathrm{~g} \mathrm{~cm}^{-3}$ ) and placed in an ultrasonic bath for $20 \mathrm{~min}$. After sonication the mixture was centrifuged for $10 \mathrm{~min}$ at $9.050 \mathrm{rcf}$. The heavy fraction was then transferred into a new tube. The light fraction and the supernatant were again sonicated for $10 \mathrm{~min}$ and then centrifuged for $10 \mathrm{~min}$ at $9.050 \mathrm{rcf}$ and the heavy fraction transferred to a new tube. This process was repeated a third time and the heavy fractions of all three runs were pooled. In step II, the pooled heavy fractions from step I were mixed with a sodium polytungstate solution (density $\rho=2.3 \mathrm{~g} \mathrm{~cm}^{-3}$ ) and processed analogously to step I. Subsequently, each of the three separated sediment fractions (A: $\rho>2.3 \mathrm{~g} \mathrm{~cm}^{-3}$, B: $2.3 \mathrm{~g} \mathrm{~cm}^{-3}>\rho>1.9 \mathrm{~g} \mathrm{~cm}^{-3}$, C: $\rho<1.9 \mathrm{~g} \mathrm{~cm}^{-3}$ ) were rinsed with deionised water until conductivity dropped below $50 \mu \mathrm{S} \mathrm{cm}^{-1}$, and then freeze-dried. In the following, sediment samples from fraction A $\left(\rho>2.3 \mathrm{~g} \mathrm{~cm}^{-3}\right)$ were analysed and are referred to as "high-density" samples.

\subsection{Analysis}

\subsubsection{Porewater}

Subsamples from each dialysis chamber were taken for the analysis of 13 parameters: 6 cations $\left(\mathrm{Na}^{+}, \mathrm{K}^{+}, \mathrm{Ca}^{2+}, \mathrm{Mg}^{2+}\right.$, $\left.\mathrm{Fe}^{2+}, \mathrm{Mn}^{2+}\right), 3$ anions $\left(\mathrm{Cl}^{-}, \mathrm{SO}_{4}^{2-}, \mathrm{NO}_{3}^{-}\right)$, dissolved inorganic carbon (DIC), free sulfides ( $\mathrm{HS}^{-}$), SRP and ammonia $\left(\mathrm{NH}_{4}^{+}\right)$. Temperature and $\mathrm{pH}$ were measured in each chamber using a pH electrode (Mettler Toledo).

Quick sampling and fixation with hypochloric acid prevented oxidation of redox-sensitive species $\left(\mathrm{Fe}^{2+}, \mathrm{Mn}^{2+}\right)$. Cations were analysed by inductively coupled plasma atomic emission spectrometry (ICP-OES, iCAP 7000series, Thermo Scientific). Anions were analysed by ion chromatography
(Shimadzu). Subsamples for DIC were stored in nitrogenflushed air-tight vessels and analysed on the day of collection using a carbon analyser (multi N/C 3100, Jena Analytics). To prevent oxidation of free sulfides subsamples from each chamber were immediately fixed with $0.2 \mathrm{M}$ zinc acetate solution. $\mathrm{HS}^{-}$was measured photometrically by applying the methylene blue method (Cline, 1969). Concentrations of SRP and $\mathrm{NH}_{4}^{+}$were determined photometrically by the molybdenum blue method (Murphy and Riley, 1962) and the indophenol method (Bolleter et al., 1961) respectively, using segmented flow analysis (Skalar Scan ${ }^{++}$, Skalar Analytical B.V.). All determinations were performed in duplicate.

\subsubsection{Sediment}

The concentrations of $\mathrm{Fe}, \mathrm{Ca}, \mathrm{Al}, \mathrm{Mg}, \mathrm{Mn}, \mathrm{S}$ and $\mathrm{P}$ were determined by ICP-OES after wet digestion $(\mathrm{HCl} 36 \%$, $\mathrm{HNO}_{3} 76 \%$, volumetric ratio $1: 3$ ) in a high-pressure microwave oven (Gigatherm). Mineral composition of sediment was characterised by powder X-ray diffraction (XRD) with a Bruker AXS D8 diffractometer equipped with $\mathrm{Cu}-$ $\mathrm{K}_{\alpha}$-radiation and a Sol-X solid state detector. Synthetic, slightly oxidised (blue appearance) vivianite powder (Dr Paul Lohmann GmbH KG) served as an internal XRD standard. The XRD patterns were measured between 5 and $60^{\circ} 2 \theta$ with a step of $0.05^{\circ} 2 \theta$ and an integration time of $12 \mathrm{~s}$. Scanning electron micrographs of sediment concretions were obtained with a FEI Quanta 600FEG field emission environmental scanning electron microscope (FE-ESEM). Sediment concretions were sputter coated with palladium prior to the analysis of elemental composition by energy dispersive X-ray spectroscopy at $15 \mathrm{kV}$ acceleration voltage (Jeol$7500 \mathrm{~F}$ scanning electron microscope) with an EDX detector (X-Max, Oxford Instruments).

Magnetic hysteresis measurements (magnetisation vs. magnetic field) of subsamples of bulk sediment and highdensity samples $\left(\rho>2.3 \mathrm{~g} \mathrm{~cm}^{-3}\right.$; sample mass ranging from about 1 to $5 \mathrm{mg}$ ) were conducted on an Alternating Gradient Magnetometer (Princeton Measurement Corporation) at room temperature in peak fields of $0.3 \mathrm{~T}$ (Flanders, 1988). Diamagnetic matter, such as calcium carbonate and quartz, demonstrates a weak negative linear dependency of induced magnetisation on the ambient magnetic field. In contrast, paramagnetic substances, such as many Fe-bearing minerals, including vivianite, show a strong and positive linear dependency of induced magnetisation on the ambient magnetic field. Finally, ferrimagnetic minerals such as magnetite exhibit a much stronger and non-linear field dependency. Their magnetisation curve is called the hysteresis loop.

The proportional factor between magnetisation and magnetic field is named magnetic susceptibility. This characteristic is field independent, i.e. linear, for dia- and paramagnetic substances, and field dependent in the case of ferrimagnetic substances. Thus, paramagnetic susceptibility may be deduced from hysteresis measurements, by calculating the 

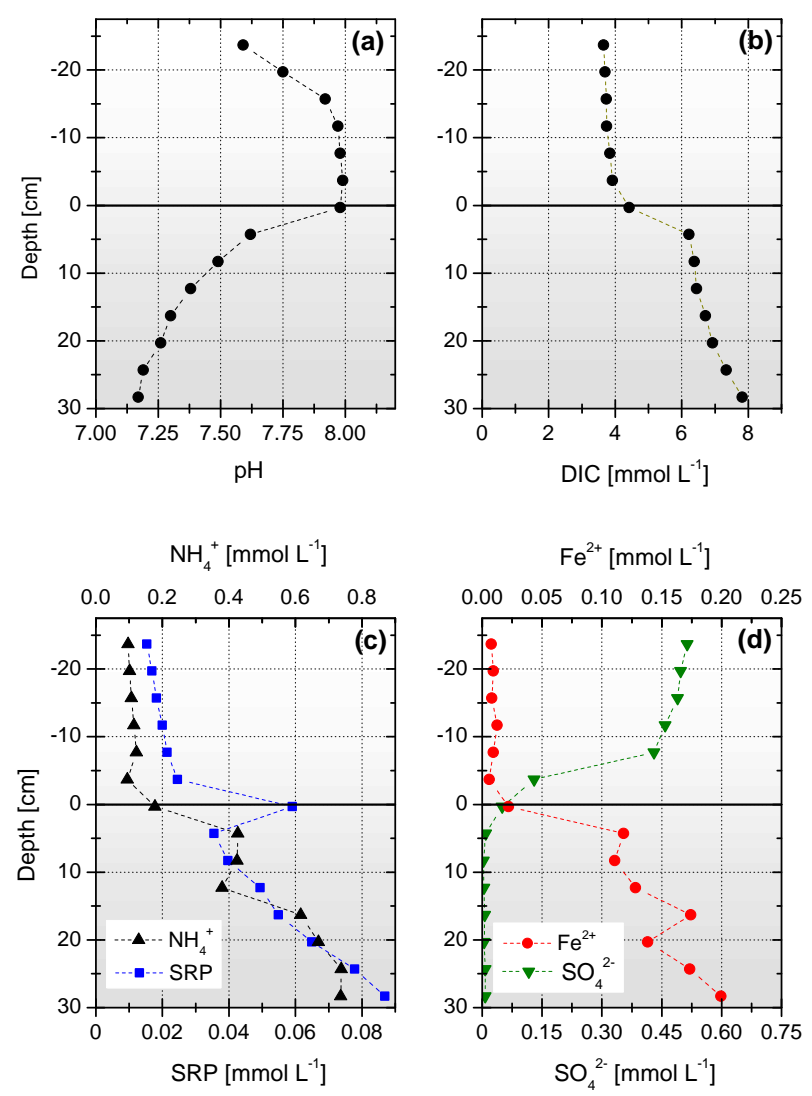

Figure 1. Vertical profiles of six parameters taken from an in situ pore water sampler deployed at the deepest point of Lake GroßGlienicke (positive downward sampling depth) (September 2013): (a) $\mathrm{pH}$, (b) dissolved inorganic carbon (DIC), (c) soluble reactive phosphorus (SRP) and ammonia $\left(\mathrm{NH}_{4}^{+}\right)$, (d) ferrous iron $\left(\mathrm{Fe}^{2+}\right)$ and sulfate $\left(\mathrm{SO}_{4}^{2-}\right)$. A depth of $0 \mathrm{~cm}$ indicates the sediment-water interface.

slope of the increasing linear part of the hysteresis loop after magnetic saturation of ferrimagnetic minerals in sufficiently strong magnetic fields. Magnetic hysteresis measurements therefore allow the determination of paramagnetic susceptibility even in the presence of magnetically much stronger ferrimagnetic minerals.

\subsection{Thermodynamic calculations}

Geochemical equilibrium calculations were based on the results of the pore water analysis using the computer program PhreeqC (version 2.18.5570) (Parkhurst et al., 1999) with minteq4 database. The database was extended to include metal complexation with dissolved organic carbon (DOC). The equilibrium constants $(\log K)$ for $1: 1$ metalligand complexes (e.g. Ca-, Fe(II)-fulvic ligand complexes) were taken from Steinmann and Shotyk (1997). The solubility constant of vivianite $\left(K_{\mathrm{viv}}=1 \times 10^{-36}\right)$ was taken from Nriagu (1972).

\section{Results}

\subsection{Chemical conditions in the pore water}

There were distinct gradients in $\mathrm{pH}$ and concentrations of $\mathrm{DIC}, \mathrm{NH}_{4}^{+}, \mathrm{SRP}, \mathrm{Fe}^{2+}$ and $\mathrm{SO}_{4}^{2-}$ across the sediment-water interface (SWI) (Fig. 1). The $\mathrm{pH}$ increased in the water body above the SWI from $\mathrm{pH}=7.60$ at $-23 \mathrm{~cm}$ to $\mathrm{pH}=$ 8.00 at the SWI, and decreased to $\mathrm{pH}=7.15$ at $29 \mathrm{~cm}$ sediment depth (Fig. 1a). The concentration of DIC was almost constant at $3.9 \mathrm{mmol} \mathrm{L}^{-1}$ in the overlying $23 \mathrm{~cm}$ of the water body above the SWI, and increased to $6 \mathrm{mmol} \mathrm{L}^{-1}$ within the upper $4 \mathrm{~cm}$ of the sediment and continuously increased down-core to reach $7.9 \mathrm{mmol} \mathrm{L}^{-1}$ at $29 \mathrm{~cm}$ sediment depth (Fig. 1b). SRP concentration increased in the water body above the SWI from $0.15 \mathrm{mmol} \mathrm{L}^{-1}$ at $-23 \mathrm{~cm}$ to $0.25 \mathrm{mmol} \mathrm{L}^{-1}$ at $-3 \mathrm{~cm}$. Directly at the SWI, SRP had a local maximum concentration of $0.59 \mathrm{mmol} \mathrm{L}^{-1}$ and increased further downcore to reach $0.87 \mathrm{mmol} \mathrm{L}^{-1}$ at $29 \mathrm{~cm}$ sediment depth (Fig. 1c). Concentration profiles of $\mathrm{NH}_{4}^{+}$and $\mathrm{Fe}^{2+}$ had a similar course: in the water body above the SWI concentrations were almost constant at $0.1 \mathrm{mmol} \mathrm{L}^{-1}$ and $0.08 \mathrm{mmol} \mathrm{L}^{-1}$, respectively, and increased by a factor of two and five respectively within the uppermost $4 \mathrm{~cm}$ of the sediment (compared to their concentrations at the SWI). Further down-core the concentrations increased to $0.74 \mathrm{mmol} \mathrm{L}^{-1}$ and $0.20 \mathrm{mmol} \mathrm{L}^{-1}$ at $29 \mathrm{~cm}$ (Fig. $1 \mathrm{c}$ and d). The $\mathrm{SO}_{4}^{2-}$ concentration showed a decreasing sigmoidal trend across the SWI, and from $4 \mathrm{~cm}$ below the SWI and deeper, the concentration was so low as to be close to the detection limit $\left(0.001 \mathrm{mmol} \mathrm{L}^{-1}\right)$ (Fig. 1d). The concentrations of $\mathrm{HS}^{-}$and $\mathrm{NO}_{3}^{-}$were not detectable.

The pore water of the sediment was supersaturated with respect to $\mathrm{Fe}(\mathrm{III})$ and mixed $\mathrm{Fe}(\mathrm{III}) / \mathrm{Fe}$ (II) phases, including magnetite, hematite, goethite and lepidocrocite. According to our equilibrium calculations, saturation indices (SI) were highest for magnetite and lowest for lepidocrocite (SI = 12.9 and 2.7, respectively) and slightly decreased with sediment depth. For vivianite, in the pore water of the sediment, there was continuous supersaturation of four orders of magnitude at depths of 4-28 cm (Fig. 2). At the SWI, the supersaturation of vivianite was about one order of magnitude lower than in subjacent pore fluids (4-28 cm), and $4 \mathrm{~cm}$ above the SWI the supersaturation was close to equilibrium. There was a sharp increase in the activity of $\mathrm{Fe}^{2+}\left(a_{\mathrm{Fe}^{2+}}\right)$ with sediment depth, as shown by plotting $a_{\mathrm{Fe}^{2+}}$ against that of $a_{\mathrm{PO}_{4}^{3-}}$ (Fig. 2). The thermodynamic calculations showed a strong subsaturation for manganese phosphate ( $\mathrm{SI} \leq-10$ ), saturation close to equilibrium for siderite $\left(\mathrm{FeCO}_{3}\right)$ and supersaturation for the calcium phosphate hydroxylapatite (SI ranged from 8 to 10) in the upper $28 \mathrm{~cm}$ of the pore water of the sediment.

To determine the effect of dissolved organic carbon (DOC) on the output of the equilibrium calculations, and in particular on $a_{\mathrm{Fe}^{2+}}$ (see e.g. Reuter and Perdue, 1977), we performed equilibrium calculations with DOC concentrations 


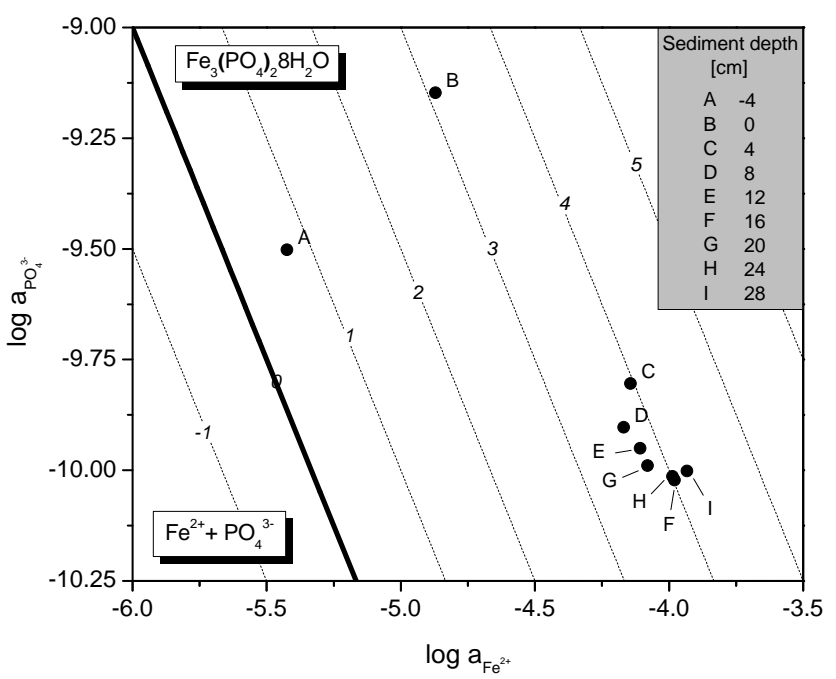

Figure 2. Degree of saturation of the pore water with respect to vivianite of Lake Groß-Glienicke in nine different sediment depths (A-I) (September 2013). Letters next to data points indicate sampling depth (positive downward sampling depth). The thick line in the diagram represents the vivianite solubility constant $K_{\text {viv }}=$ $1 \times 10^{-36}$ given by Nriagu (1972).

ranging from 10 to $500 \mathrm{mg} \mathrm{L}^{-1}$. The results showed that there is a significant decrease in $a_{\mathrm{Fe}^{2+}}$ through the formation of Fe(II)-organic-ligand complexes only at DOC concentrations above $200 \mathrm{mg} \mathrm{L}^{-1}$. As this threshold concentration is at least one order of magnitude higher than those found in the water column of Lake Groß-Glienicke, we did not include DOC as input data for equilibrium modelling.

\subsection{Structural and elemental composition of sediments}

The XRD patterns from different sediment depths showed quartz and calcium carbonate phases as well as several other minerals, e.g. dolomite, plagioclase and pyrite (for clarity not indicated in Fig. 4a) to be present in the sediment. However, the XRD reflexes characteristic for vivianite could not be identified from bulk sediment samples. The diffraction pattern of synthetic vivianite powder (blue appearance) was in coincidence with the vivianite reference pattern which use data from the Crystallography Open Database (COD). The synthetic vivianite powder changed its colour from dark blue to orange-brown and lost its characteristic diffraction pattern upon heating at $60^{\circ} \mathrm{C}$ for $24 \mathrm{~h}$ (Fig. 4a).

Examination of sediment with a reflected-light microscope revealed that dark blue nodules were present throughout the upper $23 \mathrm{~cm}$ of the sediment, but absent from subjacent sediment layers $(23-40 \mathrm{~cm})$. The heavy-liquid-separated, highdensity sediment samples (fraction A, $\rho>2.3 \mathrm{~g} \mathrm{~cm}^{-3}$, from sediment depth layers L1: $0-10 \mathrm{~cm}, \mathrm{~L} 2: 11-20 \mathrm{~cm}$, and L3: $21-30 \mathrm{~cm}$ ) were enriched with the dark blue nodules (Fig. 3a). Scanning electron micrographs of these blue nodules showed them to be spherical aggregates $(40-180 \mu \mathrm{m}$ in diameter) of platy- and needle-shaped crystals (Fig. 3b). Occasionally the aggregates also included organic debris such as diatom shells.

The XRD patterns of high-density samples from sediment layers L1, L2 and L3 showed reflexes characteristic for vivianite, and confirmed the existence of the mineral in the sediment (Fig. 4a). The abundance of blue nodules in samples from L1 and L2 was similar to each other but higher than in samples from L3 (Fig. 3a). Iron, P and Ca were most abundant of the six elements in the high-density samples from layers L1 and L2; S, Al and Mn were present at much lower concentrations (Table 1). In L3, the relative amount of Fe, $\mathrm{Ca}$, and $\mathrm{Al}$ did not significantly differ from that in $\mathrm{L} 1$ and $\mathrm{L} 2$. The relative amount of $\mathrm{P}$ of samples from $\mathrm{L} 1$ and $\mathrm{L} 2$ was similar, whereas the amount in L3 was significantly lower. For $\mathrm{S}$, the relative amount was more than four times higher in samples from L3 than in samples from L1; for Mn, the relative amount in samples from L1 and L2 was similar, whereas L3 had a significantly lower concentration.

The SEM-EDX analysis on the dark blue aggregates revealed the major elemental constituents to be $\mathrm{Fe}$ and $\mathrm{P}$, with a mean $\mathrm{Fe}: \mathrm{P}$ ratio of $1.49 \pm 0.1$ (determined from peak area, Fig. $4 \mathrm{~b}$ ), which is close to the $\mathrm{Fe}: \mathrm{P}$ ratio of vivianite $(\mathrm{Fe}$ : $\mathrm{P}=1.5$ ). The Si content was high, reaching $8 \mathrm{~mol} \%$. Minor constituents of aggregates were $\mathrm{Mn}(4 \mathrm{~mol} \%), \mathrm{Ca}(3 \mathrm{~mol} \%)$, $\mathrm{S}(2 \mathrm{~mol} \%)$ as well as $\mathrm{Mg}$ and $\mathrm{Al}$ (both $\leq 1.5 \mathrm{~mol} \%)$.

Magnetic hysteresis measurements showed that in comparison to bulk sediment, the high-density samples were enriched with paramagnetic material such as vivianite and iron sulfides $\left(\mathrm{FeS}_{\mathrm{x}}\right)$ (Fig. 5a). Both bulk sediment and highdensity samples contained ferrimagnetic material, most probably magnetite, recognised by the opening of the hysteresis loops.

The vivianite content ( $c_{\text {vivianite }}$ [weight as $\%$ of total]) in high-density samples was estimated by comparing the measured paramagnetic mass-specific susceptibility of a highdensity sample $\left(\mathrm{MS}_{\text {sample }}\left[\mathrm{m}^{3} \mathrm{~kg}^{-1}\right]\right)$ with the value given for vivianite, of $\mathrm{MS}_{\text {vivianite }}=1.05 \times 10^{-6} \mathrm{~m}^{3} \mathrm{~kg}^{-1}$ (Minyuk et al., 2013). The $\mathrm{MS}_{\text {sample values were calculated from the }}$ slope of the linear increasing part of the hysteresis loops after magnetic saturation of ferrimagnetic minerals. The relative vivianite content in a high-density sample is then given as follows:

$c_{\text {vivianite }}=\frac{\mathrm{MS}_{\text {sample }}}{\mathrm{MS}_{\text {vivianite }}} \times 100$.

This calculation is valid assuming that: (1) the contribution of diamagnetic materials, such as calcium carbonate and quartz, to the overall measured magnetic susceptibility is small, and (2) vivianite is the only paramagnetic material present in the high-density samples. Our $\mathrm{MS}_{\text {sample val- }}$ ues ranged from $1.7 \times 10^{-7}$ to $3.6 \times 10^{-7} \mathrm{~m}^{3} \mathrm{~kg}^{-1}$, which is equivalent to a relative vivianite content of 22 to 48 weight as \% of total. These values exceeded the maximum vivianite content based upon the amount of $\mathrm{P}$ present in 


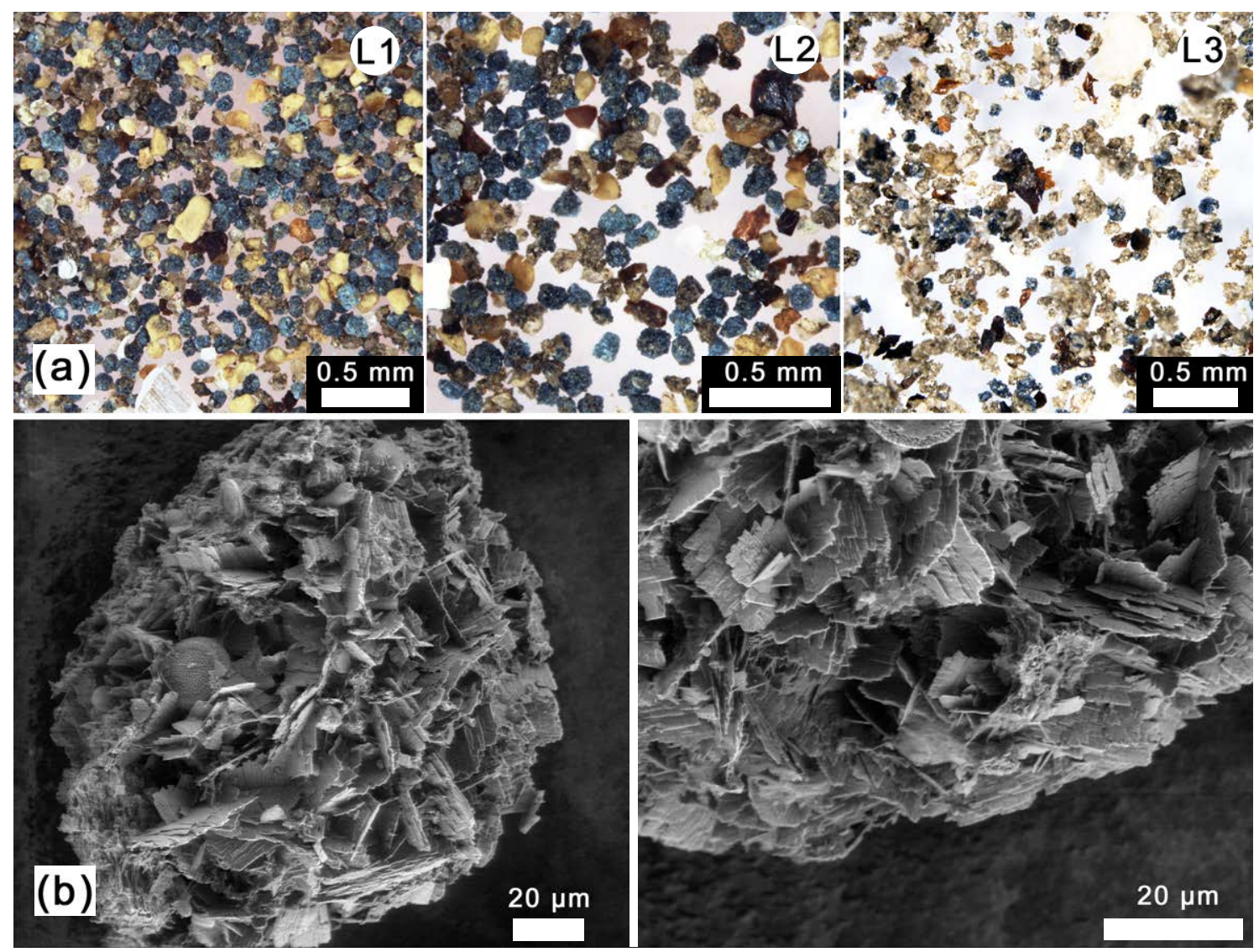

Figure 3. (a) Reflected-light microscope images of heavy-liquid separated, high-density, samples from three different sediment depths (L1: 0-10 cm, L2: 11-20 cm, L3: 21-30 cm) of Lake Groß-Glienicke. (b) Scanning electron micrographs of dark blue nodules enriched in highdensity samples from L1-L3.

Table 1. Elemental composition [mol \%] of high-density samples $\left(\rho>2.3 \mathrm{~g} \mathrm{~cm}^{-3}\right)$ from three different sediment depth layers (L1-L3) of Lake Groß-Glienicke from September 2012 and May 2013. Data are mean \pm standard deviation $(\mathrm{SD}, n=5)$.

\begin{tabular}{lcccccc}
\hline & Fe & Ca & P & S & Al & Mn \\
Sediment depth & & & & & & \\
\hline L1 $(0-10 \mathrm{~cm}) ; n=5$ & $43.0 \pm 6.3$ & $23.0 \pm 11.0$ & $23.5 \pm 2.3$ & $3.8 \pm 1.5$ & $3.4 \pm 1.3$ & $3.3 \pm 0.4$ \\
L2 $(11-20 \mathrm{~cm}) ; n=5$ & $51.2 \pm 2.3$ & $11.6 \pm 2.5$ & $23.0 \pm 2.3$ & $6.5 \pm 2.1$ & $5.1 \pm 1.5$ & $2.8 \pm 0.6$ \\
L3 $(21-30 \mathrm{~cm}) ; n=5$ & $55.9 \pm 11.4$ & $11.6 \pm 4.5$ & $13.9 \pm 1.9$ & $18.0 \pm 2.5$ & $7.4 \pm 3.0$ & $1.7 \pm 0.3$ \\
\hline
\end{tabular}

the high-density samples (Fig. 5b). To correct $\mathrm{MS}_{\text {sample for }}$ the contribution of paramagnetic $\mathrm{FeS}_{\mathrm{x}}$, we assumed all sulfur (Table 1) to be present as FeS in the high-density samples. Accordingly, high-density samples contained between 4 and 21 weight as $\%$ of total FeS. Assuming a paramagnetic mass specific susceptibility of $\mathrm{FeS}$, of $\mathrm{MS}_{\mathrm{FeS}}=$ $1.54 \times 10^{-7} \mathrm{~m}^{3} \mathrm{~kg}^{-1}$ (Lide, 2004), equation (1) can be rewritten as follows:

$$
\begin{aligned}
c_{\text {vivianite }} & =\frac{\left(\mathrm{MS}_{\text {sample }}-\mathrm{MS}_{\text {sample, } \mathrm{FeS}}\right)}{\mathrm{MS}_{\mathrm{vivianite}}} \times 100 \\
& =\frac{\left(\mathrm{MS}_{\mathrm{sample}}-\left(\mathrm{MS}_{\mathrm{FeS}} \times c_{\mathrm{FeS}}\right)\right)}{\mathrm{MS}_{\text {vivianite }}} \times 100,
\end{aligned}
$$

where $\mathrm{MS}_{\text {sample, FeS }}\left[\mathrm{m}^{3} \mathrm{~kg}^{-1}\right]$ is the contribution of paramagnetic FeS to the measured mass-specific susceptibility and $c_{\mathrm{FeS}}$ is the content of $\mathrm{FeS}$ [weight as \% of total] in a high-density sample. The FeS-corrected vivianite content in high-density samples ranged between 13 and 33 weight as $\%$ of total. These values were, except for sample $\mathrm{H} 5,1$ to $15 \%$ lower than the vivianite content derived from chemical digestion (Fig. 5b).

Relating the vivianite content in the high-density samples, calculated from chemical digestion, to the equivalent amount in bulk sediment, we were able to assess the significance of vivianite formation for the retention of $\mathrm{P}$ in 
(a)
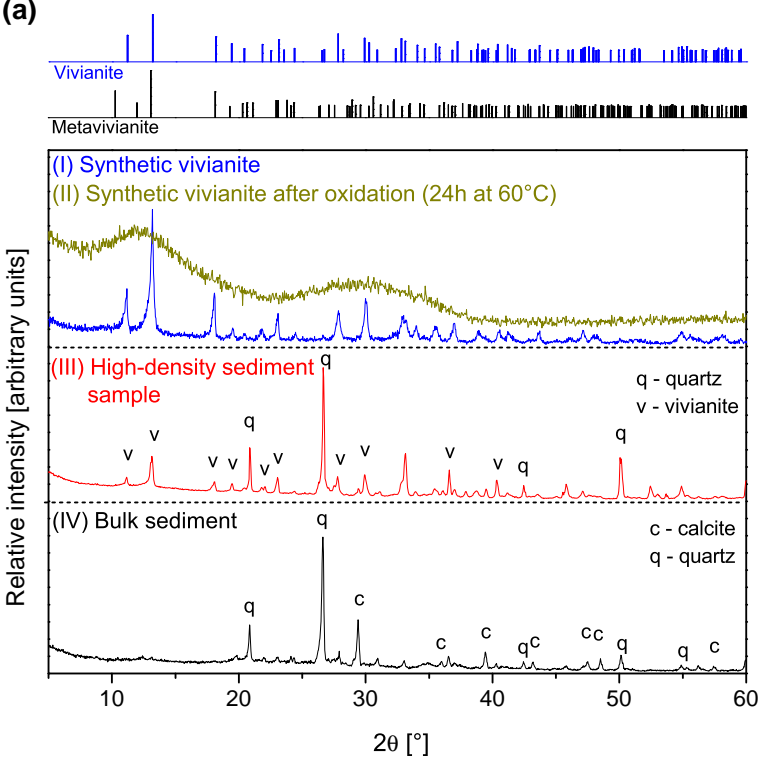

(b)

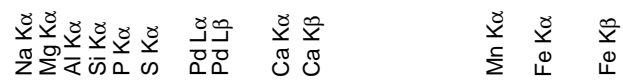

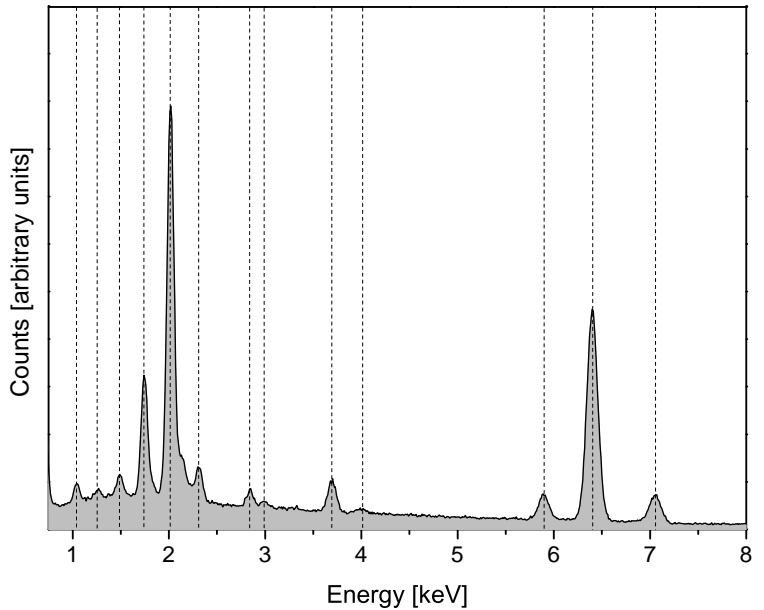

Figure 4. (a) XRD patterns of (I) synthetic vivianite, (II) synthetic vivianite after oxidation at $60^{\circ} \mathrm{C}$ for $24 \mathrm{~h}$, (III) high-density sample and (IV) bulk sediment. Characteristic reflexes of vivianite could only be observed after heavy-liquid separation in the high-density sample (III). The line patterns of vivianite (blue, file number 96-901-2899) and metavivianite (black, file number 96-100-1784) use data from the Crystallography Open Database (COD) REV 64680 (2012 edition). (b) SEM-EDX elemental spectrum obtained from a dark blue sediment concretion from Lake Groß-Glienicke. The corresponding atomic Fe:P ratio is 1.49. Elemental peaks of carbon and oxygen are omitted.
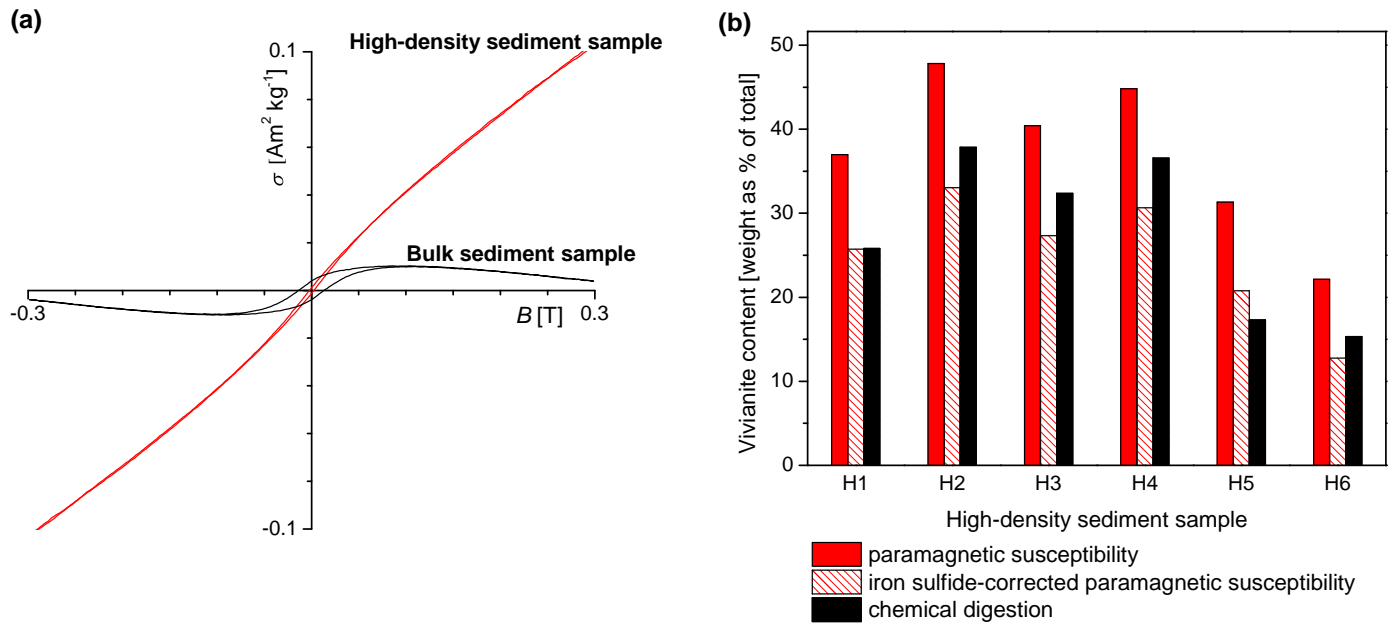

Figure 5. (a) Magnetisation $\sigma\left[\mathrm{A} \mathrm{m}^{2} \mathrm{~kg}^{-1}\right.$ ] vs. magnetic field $B$ [T], peak value $B=0.3 \mathrm{~T}$ of a high-density sample, and a bulk sediment sample from $10 \mathrm{~cm}$ sediment depth. The positive slope of the high-density sample at higher magnetic fields indicates enrichment with paramagnetic material after heavy-liquid separation. (b) Variations in vivianite content (expressed as \% weight of the sample) in each of six high-density samples, based upon paramagnetic susceptibility, iron sulfide-corrected paramagnetic susceptibility and chemical digestion.

the sediment. In samples from L1 and L2, vivianite formation accounted for $0.95 \pm 0.21 \mathrm{mg} \mathrm{g}^{-1}$ dry weight $\mathrm{P}$ and $0.96 \pm 0.16 \mathrm{mg} \mathrm{g}^{-1}$ dry weight $\mathrm{P}$, respectively (Fig. 6a). The vivianite accounts for $20 \%$ of TP concentration in the upper $20 \mathrm{~cm}$ of the sediment. In contrast, there was significantly less $\mathrm{P}$ in the high-density samples from L3 ( $0.54 \pm$ $0.13 \mathrm{mg} \mathrm{g}^{-1}$ dry weight $\mathrm{P}$ ). This lower concentration is be- cause depth layer L3 included sediment layers where no vivianite nodules were present $(24-30 \mathrm{~cm}$ sediment depth).

The vivianite-nonvivianite transition at a sediment depth of $23 \mathrm{~cm}$ coincided with a peak in sedimentary $\mathrm{Fe}$ and $\mathrm{P}$ content (Fe $80 \mathrm{mg} \mathrm{g}^{-1}$ dry weight, P $5 \mathrm{mg} \mathrm{g}^{-1}$ dry weight) (Fig. 6a and b). Above this, in the upper $23 \mathrm{~cm}$ of the sediment, the Fe (and P) content was on average 2.4 (and 3.1) times higher than in the deeper, nonvivianite-bearing 


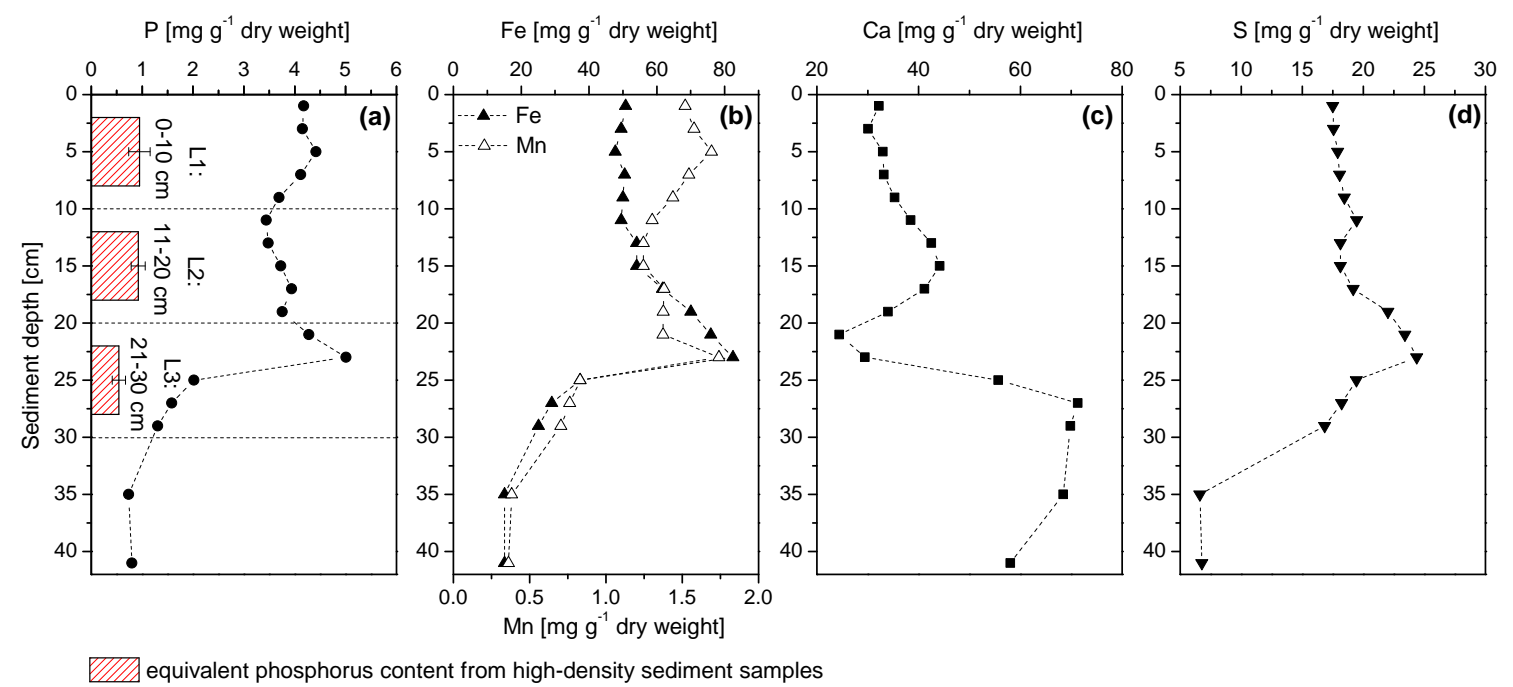

Figure 6. Sediment stratigraphic chart of (a) phosphorus (P), (b) iron (Fe) and manganese (Mn), (c) calcium (Ca) and (d) sulfur (S) of Lake Groß-Glienicke from May 2013. Bar charts in graph (a) represent the equivalent $\mathrm{P}$ content analysed in the high-density samples from depth layers L1, L2 and L3. Error bars denote $\pm \mathrm{SD}, n=5$.

sediment zone $(24-30 \mathrm{~cm}$ sediment depth). The course of manganese resembled that of $\mathrm{Fe}$ but showed an increasing trend above $12 \mathrm{~cm}$ sediment depth (Fig. 6b). Calcium content showed a reverse trend, and decreased on average by a factor of 1.9 in the vivianite-bearing sediment zone compared to the nonvivianite zone (Fig. 6c). The mean molar Fe : $\mathrm{S}$ ratio increased from 0.9 in the $25-30 \mathrm{~cm}$ sediment depth, to 1.6 in the upper $23 \mathrm{~cm}$ of vivianite bearing sediment (Fig. $6 \mathrm{~b}$ and d).

\section{Discussion}

\subsection{Identification and quantification of vivianite}

The heavy-liquid separation and the enrichment of vivianite aggregates are crucial steps for the direct identification of vivianite by X-ray diffraction. In our study, X-ray diffraction was successful, even though the vivianite nodules were partially oxidised due to contact with air (Figs. 3a and 4a) and already are an alteration product of unoxidised, pristine vivianite. The diffraction pattern of synthetic vivianite powder, both in its slightly oxidised form (blue appearance) and after heating at $60^{\circ} \mathrm{C}$ for $24 \mathrm{~h}$ supported that the vivianite nodules detected in the sediment were slightly surfaceoxidised only and did not lose their characteristic diffraction pattern upon freeze-drying and exposure to air. Comparing the diffraction pattern of the high-density sample with the reference diffraction pattern of vivianite and metavivianite (which accounts for a partial oxidation of Fe(II)) there was even a higher conformity with the vivianite reference pattern than with the metavivianite reference pattern (Fig. 4a). This finding confirms that an aerobic handling of sediment does not lead to a significant oxidation of vivianite and the mineral is detectable by X-ray diffraction even after contact with air; this is contrary to what has been reported by Olsson et al. (1997) and März et al. (2008). According to these studies, vivianite is not expected to be detectable by X-ray diffraction after contact with air due to its high sensitivity towards oxidation. Aerobic handling of sediment and freeze-drying, however, might have impacted the speciation of sulfur - i.e. crystalline $\mathrm{FeS}_{2}$ and $\mathrm{FeS}$ might have been oxidised and altered to amorphous phases (Hjorth, 2004).

EDX analysis and scanning electron microscopy reveal fundamental characteristics of the mineral aggregates, and a conventional reflected-light microscope allows identification of single vivianite nodules out of bulk sediments. Thus, a combination of techniques allowed a qualitative investigation of vivianite deposits in different sediment layers and comparison with results from saturation calculations.

The enrichment of high-density samples with vivianite nodules further allowed us to assess the amount of vivianite present in the sediment. To estimate the quantity of vivianite in high-density sediment samples, the vivianite content was calculated based upon two different methods: (1) chemical digestion, and (2) magnetic hysteresis measurements. The latter method provides a different, and independent approach to estimate the vivianite content, taking advantage of the heavy-liquid separation of sediment samples and the paramagnetic nature of vivianite. 


\subsection{Contribution of vivianite to phosphorus retention}

The presence of vivianite within the first centimetre of the lacustrine sediment of freshwater Lake Groß-Glienicke shows that vivianite is currently forming. The incorporation of diatom shells and other organic debris within the nodules confirms their authigenic origin (Fig. 3b). The occurrence of vivianite nodules in a recent and unlayered sediment horizon distinguishes the vivianite finding described here from Lake Groß-Glienicke from the vivianite deposits regularly detected in palaeolimnetic core records (e.g. Brauer et al., 1999; Sapota et al., 2006; Minyuk et al., 2013).

In the high-density samples from layers L1 $(0-10 \mathrm{~cm})$ and L2 $(11-20 \mathrm{~cm})$ there was a higher amount of vivianite nodules than in samples from layer L3 $(21-30 \mathrm{~cm})$. These observations are reflected in the $\mathrm{P}$ content of the high-density sediment samples. In samples from L1 and L2 the P content was similar (to each other), whereas samples from L3 contained significantly less $\mathrm{P}$.

Due to the high enrichment of vivianite nodules in the high-density samples, the $\mathrm{P}$ content that we determined mainly represented the amount of $\mathrm{P}$ bound in vivianite. We cannot exclude that part of the $\mathrm{P}$ analysed in the high-density samples originated from compounds other than vivianite, such as $\mathrm{P}$ sorbed onto the surface of Fe(III) minerals which resisted reductive dissolution, $\mathrm{Ca}$-associated $\mathrm{P}$, or other $\mathrm{Fe}$ phosphates. These compounds were expected to accumulate in the high-density samples as their density is higher than $2.3 \mathrm{~g} \mathrm{~cm}^{-3}$ and chemical digestion data confirmed the presence of $\mathrm{Ca}$ and high content of Fe in these samples (Table 1). However, our results from magnetic susceptibility measurements support the assumption that the amount of $\mathrm{P}$ analysed in the high-density samples could mainly be attributed to vivianite-bound $P$.

Provided that the weakening of the measured positive magnetisation due to the presence of diamagnetic $\mathrm{Si}$ and $\mathrm{Ca}$ compounds is small, the vivianite content can be determined from paramagnetic susceptibility. This assumption is valid, since the values of the diamagnetic mass-specific susceptibility of $\mathrm{SiO}_{2}$ and $\mathrm{CaCO}_{3}$ are more than two orders of magnitude smaller than that of vivianite (Lide, 2004). Even if highdensity samples contained 3-5 times more diamagnetic $\mathrm{SiO}_{2}$ and $\mathrm{CaCO}_{3}$ than vivianite, the correspondent weakening of the positive magnetisation was negligible. The contribution of paramagnetic $\mathrm{FeS}_{\mathrm{X}}$ to the measured positive magnetisation of high-density samples was significant (Fig. 5b) when assuming all sulfur to be present as FeS. For the susceptibility correction we used the $\mathrm{MS}_{\mathrm{FeS}}$ value given by Lide (2004). The FeS correction could account for the overestimation of the vivianite content derived from uncorrected magnetic susceptibility data. The FeS-corrected vivianite contents were, except for one sample, lower than values derived from chemical digestion. However, it is important to note that the relative changes in vivianite content between different highdensity samples were determined similarly by both the chem- ical digestion and the FeS-corrected paramagnetic susceptibility methods (Fig. 5). Considering the range of a factor of two for the mass-specific magnetic susceptibility of vivianite (Minyuk et al., 2013), the vivianite contents determined by both the chemical digestion and the FeS-corrected paramagnetic susceptibility methods match acceptably.

Furthermore, a high-density sediment sample from $35 \mathrm{~cm}$ sediment depth (data not shown), containing no vivianite nodules, demonstrated a negative susceptibility at higher magnetic fields, indicative of a majority of diamagnetic material present in the high-density sediment sample. The $\mathrm{P}$ content of this sample accounted only for $0.05 \mathrm{mg} \mathrm{g}^{-1}$ dry weight $\mathrm{P}$ which is less than $6 \%$ of the $\mathrm{P}$ content detected in high-density samples from L1 and L2. The good agreement between results from magnetic susceptibility measurements and chemical digestion confirmed that the amount of $\mathrm{P}$ analysed in the high-density samples in sediment layers L1-L3 mainly represented vivianite-bound P.

Although the sediment preparation method we used neglected vivianite nodules smaller than $80 \mu \mathrm{m}$ in diameter, the amount of vivianite present in the high-density samples serves as a reliable proxy for the overall vivianite content in the sediment. The sieving step was applied in order to maximise the enrichment of vivianite nodules in high-density samples and minimise the relative amount of small-sized $(<$ $80 \mu \mathrm{m}) \mathrm{Si}$ and $\mathrm{Ca}$ compounds at the same time.

Our results suggest a homogeneous vivianite content in the upper $20 \mathrm{~cm}$ of the sediment. Vivianite formation significantly contributed to $\mathrm{P}$ retention in Lake Groß-Glienicke, accounting for $20 \%$ of the total sedimentary $\mathrm{P}$ in the upper $20 \mathrm{~cm}$ of the sediment (Fig. 6). Assuming an increase in total sedimentary $\mathrm{P}$ due to the artificial application of Fe during lake restoration of $2.5 \mathrm{mg} \mathrm{g}^{-1}$ in the upper $20 \mathrm{~cm}$ of the sediment in comparison to sediment layers deposited prior to the in-lake measure, vivianite formation could explain about $40 \%$ of this increase. The remaining $60 \%$ of increase in total sedimentary $\mathrm{P}$ might be due to Fe(III)-phases which sorb $\mathrm{P}$, and mixed $\mathrm{Fe}$ (III)/Fe(II) phosphate minerals, which resisted reductive dissolution within the anoxic sediment matrix (Hyacinthe and Van Cappellen, 2004; Lehtoranta et al., 2009). Redox-sensitive $\mathrm{Fe}(\mathrm{III})$-phases could be preserved by a protective coating of $\mathrm{FeS}_{\mathrm{x}}$ preventing further reduction (De Vitre et al., 1988). Moreover, $P$ originating from preserved organic material, which co-precipitated during iron oxidation, could significantly contribute to the increase in $\mathrm{P}$ burial after the addition of Fe during lake restoration (Lalonde et al., 2012). The presence of these compounds may explain the peak in $\mathrm{P}$ and Fe content at the sediment depth of $23 \mathrm{~cm}$, even though no elevated vivianite contents could be detected at this depth. 


\subsection{Prediction of vivianite formation by saturation calculations}

Changes in $\mathrm{pH}$ and dissolved substances across the SWI (Fig. 1) are due to the deposition of organic and inorganic matter, and its subsequent microbial decomposition. Along with the liberation of SRP and $\mathrm{Fe}^{2+}$ there was moderate vivianite supersaturation $(\mathrm{SI}=3-4)$ throughout the upper $30 \mathrm{~cm}$ of the sediment (Fig. 2). The decrease in orthophosphate activity with sediment depth is due to the declining $\mathrm{pH}$ counteracting the concomitant increase of SRP concentration with depth. While the activity of $\mathrm{H}^{+}$and SRP varied by a similar factor, the variation in $\mathrm{pH}$ has a stronger influence on the saturation state of vivianite than does the change in SRP concentration. Since simultaneous with the decrease in orthophosphate activity, the activity of $\mathrm{Fe}^{2+}$ increased with depth, the degree of vivianite supersaturation persisted. The degree of supersaturation underlines that mineral formation is slow, and not governed by the saturation state of the pore water but rather by another process, as proposed by Postma (1981) and Emerson and Widmer (1978). According to those studies crystal growth is driven by surface reactions and is not diffusion controlled. Formation of siderite $\left(\mathrm{FeCO}_{3}\right)$ which potentially competes with vivianite for $\mathrm{Fe}^{2+}$ is supposed to be controlled by very slow precipitation kinetics (Postma, 1981). Therefore, it is unlikely that the nearequilibrium conditions we report for Lake Groß-Glienicke indicate siderite precipitation. No crystalline siderite could be identified in the high-density samples using the XRD pattern.

According to these saturation calculations, and from a thermodynamic point of view, the precipitation of vivianite was favoured in the upper $30 \mathrm{~cm}$ of the sediment. The present geochemical conditions, with relatively high $\mathrm{Fe}^{2+}$ concentrations (0.02 to $\left.0.2 \mathrm{mmol} \mathrm{L}^{-1}\right)$ and high SRP concentrations $\left(0.04\right.$ to $\left.0.09 \mathrm{mmol} \mathrm{L}^{-1}\right)$, at neutral to slightly alkaline $\mathrm{pH}$ in the absence of free sulfides, plot within the stability field of vivianite proposed by Nriagu (1972) and Nriagu and Dell (1974). However, to rely upon these calculations to predict in situ vivianite formation omits consideration of a key feature, namely the sharp transition between the vivianite-bearing and nonvivianite-bearing sediment layers. Vivianite was only present in the upper $23 \mathrm{~cm}$ of the sediment, not in subjacent sediment layers even though the pore water was supersaturated at sediment depths of 24 and $28 \mathrm{~cm}$. Assuming constant precipitation of vivianite from supersaturated pore water, the highest concentrations of vivianite should be in sediment layers which have been supersaturated the longest time, for example in the sediment deposited shortly after the iron addition. However, this was not the case for Lake Groß-Glienicke. From our findings, it is therefore questionable whether supersaturated pore water alone is a reliable predictor of the in situ formation of vivianite.

\subsection{Processes influencing vivianite formation}

We consider that the Fe application in 1992/93 was the stimulus for vivianite formation in Lake Groß-Glienicke. In 2003 Gächter and Müller (2003) used a simple conceptual model to explain that an increasing ratio of reactive $\mathrm{Fe}$ (II) to reactive $\mathrm{P}$ leads to an increased permanent $\mathrm{P}$ burial through the formation of a solid ferrous iron phosphate, such as vivianite. It is exactly that shift in geochemical conditions which led to the favourable conditions for vivianite formation in Lake Groß-Glienicke. During restoration of Lake Groß-Glienicke Fe was provided in surplus. As a consequence, not all reactive $\mathrm{Fe}$ (II) is precipitated as solid $\mathrm{FeS}_{\mathrm{x}}$ but can react with $\mathrm{PO}_{4}^{3-}$ to form stable $\mathrm{Fe}(\mathrm{II})$-phosphate minerals (Gächter and Müller, 2003; Kleeberg et al., 2013). The relative S content in the sediment decreased after the artificial application of iron and explains why high-density samples from L1 and L2 contained less S than samples from L3 (Table 1).

The $\mathrm{Fe}$ and $\mathrm{Mn}$ content is elevated throughout the upper $23 \mathrm{~cm}$ of the sediment (Fig. 6), because there has been a continuous cycling of both elements between their dissolved and particulate forms at the SWI after the Fe application. This feature reflects the change in redox conditions in the hypolimnion and at the SWI after the Fe supplement, i.e. the sediment surface has become more oxidised. A high reactive $\mathrm{Fe}(\mathrm{II})$ concentration led in turn to the formation of vivianite in freshly deposited sediments after the Fe application. The layer of formation of vivianite is the uppermost sediment horizon close to the SWI. This explains the homogeneous vivianite content in the upper $20 \mathrm{~cm}$ of the sediment, and emphasises that supersaturated pore water alone is not sufficient to cause vivianite formation.

At the SWI, fresh organic matter is decomposed, and iron(oxy)hydroxides undergo reductive dissolution, leading to the release of $\mathrm{Fe}^{2+}$, SRP from organic matter, and the liberation of previously adsorbed $\mathrm{PO}_{4}^{3-}$ from iron(oxy)hydroxides. The presence of vivianite aggregates in association with organic matter or organic-rich deposits has been reported by numerous authors (Mackereth, 1966; Kjensmo, 1968; Rosenqvist, 1970; Postma, 1981; Peretyazhko and Sposito, 2005; Taylor et al., 2008), suggesting a crucial function of this organic material for the formation of crystal aggregates. The gel-like pore structure of a sediment matrix rich in organic matter, in combination with an intensified release of SRP and $\mathrm{Fe}^{2+}$ due to microbial activity, may serve as necessary prerequisite for vivianite formation in sediments. Through the activity of bacteria, cell-mediated microenvironments within the sediment matrix may evolve, sustaining vivianite-supersaturation during crystal growth, even on a small scale (Cosmidis et al., 2014). Hydrophic, negatively charged, carbon-rich fibres which build up a structure of walls within the sediment may thereby catalyse the growth of seed crystals (Zelibor et al., 1988). 


\section{Conclusions}

Heavy-liquid separation of sediment leads to an enrichment of vivianite nodules in high-density samples, and is key to demonstrating the presence of vivianite by X-ray diffraction. The enrichment achieved after sediment preparation, and combination of the results from standard chemical digestion and magnetic hysteresis measurements, allow quantification of the $\mathrm{P}$ bound in vivianite for different sediment depths. However, the absence of vivianite from layers of sediment that are supersaturated with pore water constrains the validity of equilibrium calculations regarding the in situ precipitation and occurrence of vivianite. At our study site at Lake Groß-Glienicke, formation of vivianite was triggered by an artificial $\mathrm{Fe}$ supplement, and explains $20 \%$ of total $\mathrm{P}$ in sediment layers deposited after the in-lake measure. Our results emphasise the role of $\mathrm{Fe}$, and the formation of vivianite in particular, in the long-term retention of $\mathrm{P}$ in the sediment, which enabled the system to recover from its former eutrophic state to its current mesotrophic level.

Acknowledgements. The authors are grateful to Hans-Jürgen Exner and Elke Zwirnmann (IGB Berlin) for ICP, DIC and IC analysis. Susann Weichold and Ingrid Zenke (Max Planck Institute of Colloids and Interfaces) are acknowledged for SEM and XRD assistance, and Sarah Poynton for the linguistic improvement of the text. The constructive comments by T. Jilbert and two anonymous reviewers are gratefully acknowledged. The study was funded by the German DFG project "RedoxPhos" HU 740/5-1.

Edited by: C. P. Slomp

\section{References}

Berner, R. A.: A new geochemical classification of sedimentary environments, J. Sediment. Res., 51, 359-365, 1981.

Bolleter, W., Bushman, C., and Tidwell, P.: Spectrophotometric determination of ammonia as indophenol, Anal. Chem., 33, 592594, 1961.

Borch, T. and Fendorf, S.: Phosphate interactions with iron (hydr)oxides: mineralization pathways and phosphorus retention upon bioreduction, in: Adsorption of Metals by Geomedia II: Variables, Mechanisms, and Model Applications, edited by: Barnett, M. O. and Kent, D. B., vol. 7 of Developments in Earth and Environmental Sciences, 321-348, Elsevier, 2007.

Brauer, A., Endres, C., Günter, C., Litt, T., Stebich, M., and Negendank, J. F.: High resolution sediment and vegetation responses to Younger Dryas climate change in varved lake sediments from Meerfelder Maar, Germany, Quaternary Sci. Rev., 18, 321-329, 1999.

Cline, J.: Spectrophotometric determination of hydrogen sulfide in natural waters, Limnol. Oceanogr., 14, 454-458, 1969.

Cosmidis, J., Benzerara, K., Morin, G., Busigny, V., Lebeau, O., Jézéquel, D., Noël, V., Dublet, G., and Othmane, G.: Biomineralization of iron-phosphates in the water column of Lake Pavin
(Massif Central, France), Geochim. Cosmochim. Ac., 126, 7896, doi:10.1016/j.gca.2013.10.037, 2014.

De Vitre, R., Buffle, J., Perret, D., and Baudat, R.: A study of iron and manganese transformations at the $\mathrm{O}_{2} / \mathrm{S}(-\mathrm{II})$ transition layer in a eutrophic lake (Lake Bret, Switzerland): a multimethod approach, Geochim. Cosmochim. Ac., 52, 1601-1613, doi:10.1016/0016-7037(88)90229-3, 1988.

Emerson, S. and Widmer, G.: Early diagenesis in anaerobic lake sediments - II. Thermodynamic and kinetic factors controlling the formation of iron phosphate, Geochim. Cosmochim. Ac., 42, 1307-1316, doi:10.1016/0016-7037(78)90035-2, 1978.

Fagel, N., Alleman, L., Granina, L., Hatert, F., Thamo-Bozso, E., Cloots, R., and André, L.: Vivianite formation and distribution in Lake Baikal sediments, Global Planet. Change, 46, 315-336, 2005.

Flanders, P.: An alternating-gradient magnetometer, J. Appl. Phys., 63, 3940-3945, 1988.

Gächter, R. and Müller, B.: Why the phosphorus retention of lakes does not necessarily depend on the oxygen supply to their sediment surface, Limnol. Oceanogr., 48, 929-933, 2003.

Hearn, P. P., Parkhurst, D. L., and Callender, E.: Authigenic vivianite in Potomac River sediments - control by ferric oxyhydroxides, J. Sediment. Petrol., 53, 165-177, 1983.

Hesslein, R. H.: An in situ sampler for close interval pore water studies, Limnol. Oceanogr., 21, 912-914, 1976.

Hjorth, T.: Effects of freeze-drying on partitioning patterns of major elements and trace metals in lake sediments, Anal. Chim. Acta, 526, 95-102, 2004.

Hupfer, M. and Lewandowski, J.: Oxygen Controls the Phosphorus Release from Lake Sediments - a Long-Lasting Paradigm in Limnology, Int. Rev. Hydrobiol., 93, 415-432, 2008.

Hush, N.: Intervalence-transfer absorption. Part 2. Theoretical considerations and spectroscopic data, in: Progress in Inorganic Chemistry, edited by: Cotton, F. A., vol. 8, Interscience Publishers, Hoboken, NJ, USA, 391 pp., 1967.

Hyacinthe, C. and Van Cappellen, P.: An authigenic iron phosphate phase in estuarine sediments: composition, formation and chemical reactivity, Mar. Chem., 91, 227-251, doi:10.1016/j.marchem.2004.04.006, 2004.

Jilbert, T. and Slomp, C. P.: Iron and manganese shuttles control the formation of authigenic phosphorus minerals in the euxinic basins of the Baltic Sea, Geochim. Cosmochim. Ac., 107, 155169, doi:10.1016/j.gca.2013.01.005, 2013.

Katsev, S., Tsandev, I., L'Heureux, I., and Rancourt, D. G.: Factors controlling long-term phosphorus efflux from lake sediments: Exploratory reactive-transport modeling, Chem. Geol., 234, 127-147, doi:10.1016/j.chemgeo.2006.05.001, 2006.

Kjensmo, J.: Late and post-glacial sediments in the small meromictic Lake Svinsjøen, Arch. Hydrobiol., 65, 125-141, 1968.

Kleeberg, A., Köhler, A., and Hupfer, M.: How effectively does a single or continuous iron supply affect the phosphorus budget of aerated lakes?, J. Soil. Sediment., 12, 1593-1603, doi:10.1007/s11368-012-0590-1, 2012.

Kleeberg, A., Herzog, C., and Hupfer, M.: Redox sensitivity of iron in phosphorus binding does not impede lake restoration, Water Res., 47, 1491-1502, doi:10.1016/j.watres.2012.12.014, 2013.

Lalonde, K., Mucci, A., Ouellet, A., and Gélinas, Y.: Preservation of organic matter in sediments promoted by iron, Nature, 483, 198-200, 2012. 
Lehtoranta, J., Ekholm, P., and Pitkanen, H.: Coastal eutrophication thresholds: a matter of sediment microbial processes, Ambio, 38, 303-308, 2009.

Lide, D. R.: CRC handbook of chemistry and physics, CRC press, 2004.

Lindsay, W. L., Vlek, P. L., and Chien, S. H.: Phosphate minerals, in: Minerals in Soil Environments, edited by: Dixon, J. B. and Weed, S. B., SSSA Book Series, Soil Science Society of America, 1089-1130, 1989.

Mackereth, F. J. H.: Some chemical observations on postglacial lake sediments, Philos. T. Roy. Soc. B, 250, 165-213, doi:10.1098/rstb.1966.0001, 1966.

Manning, P., Murphy, T., and Prepas, E.: Intensive formation of vivianite in the bottom sediments of mesotrophic Narrow Lake, Alberta, Can, Mineral., 29, 77-85, 1991.

März, C., Hoffmann, J., Bleil, U., de Lange, G., and Kasten, S.: Diagenetic changes of magnetic and geochemical signals by anaerobic methane oxidation in sediments of the Zambezi deep-sea fan (SW Indian Ocean), Mar. Geol., 255, 118-130, doi:10.1016/j.margeo.2008.05.013, 2008.

Minyuk, P. S., Subbotnikova, T. V., Brown, L. L., and Murdock, K. J.: High-temperature thermomagnetic properties of vivianite nodules, Lake El'gygytgyn, Northeast Russia, Clim. Past, 9, 433-446, doi:10.5194/cp-9-433-2013, 2013.

Moosmann, L., Gächter, R., Müller, B., and Wüest, A.: Is phosphorus retention in autochthonous lake sediments controlled by oxygen or phosphorus?, Limnol. Oceanogr., 51, 763-771, 2006.

Murphy, J. and Riley, J.: A modified single solution method for the determination of phosphate in natural waters, Anal. Chim. Acta, 27, 31-36, doi:10.1016/S0003-2670(00)88444-5, 1962.

Nanzyo, M., Onodera, H., Hasegawa, E., Ito, K., and Kanno, H.: Formation and dissolution of vivianite in paddy field soil, Soil Sci. Soc. Am. J., 77, 1452-1459, doi:10.2136/sssaj2012.0437n, 2013.

Nembrini, G. P., Capobianco, J. A., Viel, M., and Williams, A. F.: A Mössbauer and chemical study of the formation of vivianite in sediments of Lago Maggiore (Italy), Geochim. Cosmochim. Ac., 47, 1459-1464, doi:10.1016/0016-7037(83)90304-6, 1983.

Nriagu, J.: Stability of vivianite and ion-pair formation in the system $\mathrm{Fe}_{3}\left(\mathrm{PO}_{4}\right)_{2}-\mathrm{H}_{3} \mathrm{PO}_{4}-\mathrm{H}_{2} \mathrm{O}$, Geochim. Cosmochim. Ac., 36, 459-470, 1972.

Nriagu, J. and Dell, C.: Diagenetic formation of iron phosphates in recent lake sediments, Am. Mineral., 59, 934-946, 1974.

O’Loughlin, E. J., Boyanov, M. I., Flynn, T. M., Gorski, C. A., Hofmann, S. M., McCormick, M. L., Scherer, M. M., and Kemner, K. M.: Effects of bound phosphate on the bioreduction of lepidocrocite $(\mathrm{y}-\mathrm{FeOOH})$ and maghemite $\left(\mathrm{y}-\mathrm{Fe}_{2} \mathrm{O}_{3}\right)$ and formation of secondary minerals, Environ. Sci. Technol., 47, 91579166, doi:10.1021/es400627j, 2013.

Olsson, S., Regnell, J., Persson, A., and Sandgren, P.: Sedimentchemistry response to land-use change and pollutant loading in a hypertrophic lake, southern Sweden, J. Paleolimnol., 17, 275294, doi:10.1023/A:1007967832177, 1997.

Parkhurst, D. L. and Appelo, C. A. J.: User's guide to PHREEQC (Version 2): a computer program for speciation, batch-reaction, one-dimensional transport, and inverse geochemical calculations, Water-Resources Investigations Report, US Geological Survey: Earth Science Information Center, 1999.
Peretyazhko, T. and Sposito, G.: Iron(III) reduction and phosphorous solubilization in humid tropical forest soils, Geochim. Cosmochim. Ac., 69, 3643-3652, doi:10.1016/j.gca.2005.03.045, 2005.

Postma, D.: Formation of siderite and vivianite and the pore-water composition of a recent bog sediment in Denmark, Chem. Geol., 31, 225-244, 1981.

Reuter, J. H. and Perdue, E. M.: Importance of heavy metal-organic matter interactions in natural waters, Geochim. Cosmochim. Ac., 41, 325-334, 1977.

Roden, E. E. and Edmonds, J. W.: Phosphate mobilization in iron-rich anaerobic sediments: microbial Fe(III) oxide reduction versus iron-sulfide formation, Arch. Hydrobiol., 139, 347-378, 1997.

Rosenqvist, I.: Formation of vivianite in Holocene clay sediments, Lithos, 3, 327-334, 1970.

Ruttenberg, K. C.: Development of a sequential extraction method for different forms of phosphorus in marine sediments, Limnol. Oceanogr., 37, 1460-1482, 1992.

Sapota, T., Aldahan, A., and Al-Aasm, I. S.: Sedimentary facies and climate control on formation of vivianite and siderite microconcretions in sediments of Lake Baikal, Siberia, J. Paleolimnol., 36, 245-257, doi:10.1007/s10933-006-9005-x, 2006.

Søndergaard, M., Jensen, J., and Jeppesen, E.: Retention and internal loading of phosphorus in shallow, eutrophic lakes, Scientific World Journal, 1, 427-442, doi:10.1100/tsw.2001.72, 2001.

Steinmann, P. and Shotyk, W.: Chemical composition, pH, and redox state of sulfur and iron in complete vertical porewater profiles from two Sphagnum peat bogs, Jura Mountains, Switzerland, Geochim. Cosmochim. Ac., 61, 1143-1163, doi:10.1016/S0016-7037(96)00401-2, 1997.

Stigebrandt, A., Rahm, L., Viktorsson, L., Ödalen, M., Hall, P. O., and Liljebladh, B.: A new phosphorus paradigm for the Baltic proper, AMBIO, 1-10, http://link.springer.com/journal/13280/ onlineFirst/page/2, 2013.

Taylor, K. G., Hudson-Edwards, K. A., Bennett, A. J., and Vishnyakov, V.: Early diagenetic vivianite $\left[\mathrm{Fe}_{3}(\mathrm{PO} 4)_{2} \cdot 8 \mathrm{H}_{2} \mathrm{O}\right]$ in a contaminated freshwater sediment and insights into zinc uptake: A $\mu$-EXAFS, $\mu$-XANES and Raman study RID, Appl. Geochem., 23, 1623-1633, doi:10.1016/j.apgeochem.2008.01.009, 2008.

Walpersdorf, E., Koch, C. B., Heiberg, L., O’Connell, D., Kjaergaard, C., and Hansen, H. B.: Does vivianite control phosphate solubility in anoxic meadow soils?, Geoderma, 193-194, 189199, doi:10.1016/j.geoderma.2012.10.003, 2013.

Wolter, K.-D.: Restoration of eutrophic lakes by phosphorus precipitation, with a case study on Lake Gross-Glienicker, in: Restoration of Lakes, Streams, Floodplains, and Bogs in Europe, edited by: Eiseltová, M., vol. 3 of Wetlands: Ecology, Conservation and Management, Springer Netherlands, 85-99, 2010.

Zelibor, J. J., Senftle, F., and Reinhardt, J.: A proposed mechanism for the formation of spherical vivianite crystal aggregates in sediments, Sediment. Geol., 59, 125-142, doi:10.1016/00370738(88)90103-0, 1988. 